\title{
The fate and tissue disposition of deoxynivalenol in broiler chickens
}

\author{
Sasithorn PRALATNET ${ }^{1}$, Saranya POAPOLATHEP ${ }^{1)}$, Kanjana IMSILP ${ }^{1)}$, Phanwimol TANHAN ${ }^{1)}$, \\ Supaporn ISARIYODOM ${ }^{2)}$, Susumu KUMAGAI ${ }^{3)}$ and Amnart POAPOLATHEP ${ }^{1) *}$ \\ ${ }^{1)}$ Department of Pharmacology, Faculty of Veterinary Medicine, Kasetsart University, Bangkok 10900, Thailand \\ ${ }^{2)}$ Department of Animal Science, Faculty of Agriculture, Kasetsart University, Bangkok 10900, Thailand \\ ${ }^{3)}$ Research Center for Food Safety, Graduate School of Agricultural and Life Sciences, The University of Tokyo, Tokyo 113-8657, Japan
}

(Received 19 December 2014/Accepted 21 March 2015/Published online in J-STAGE 4 April 2015)

ABSTRACT. To evaluate the fate of deoxynivalenol (DON) in broilers, DON was administered either intravenously or orally to broilers at a dose of $1 \mathrm{mg} / \mathrm{kg} \mathrm{BW}$. Concentrations of DON in plasma were measurable up to $4 \mathrm{hr}$ and $2 \mathrm{hr}$ after intravenous and oral administration, respectively. Following intravenous administration, the values for the elimination half-life, the volume of distribution and the clearance were $1.25 \pm 0.25 \mathrm{hr}, 7.55 \pm 2.03 \mathrm{l} / \mathrm{kg}$ and $4.16 \pm 0.42 \mathrm{l} / \mathrm{hr} / \mathrm{kg}$, respectively. The oral bioavailability was $15.46 \pm 4.02 \%$. DON was detectable in all tissues examined after oral administration. These results suggest that DON is able to penetrate into the various tissues in broilers, though poorly absorbed from their gastrointestinal tract.

KEY WORDS: broiler, deoxynivalenol, fate residue, residue broilers

doi: 10.1292/jvms.14-0676; J. Vet. Med. Sci. 77(9): 1151-1155, 2015

Deoxynivalenol (DON, vomitoxin) is a most commonly occurring trichothecene mycotoxin produced by several plant pathogenic fungi, of which Fusarium graminearum and Fusarium culmorum are the most important sources. DON contamination has been found in a variety of foodstuffs worldwide, including wheat, maize, barley, oats, rice and feed for farm animals [5, 10-12, 33] (http://www.efsa. europa.eu/de/efsajournal/doc/73.pdf; http://www.who.int/ foodsafety/chem/summary 72 rev.pdf) and also in cereals in South America, Canada, European Union countries, etc. [14]. The contamination has accompanied with various adverse health effects, such as feed refusal, anorexia, weight loss, vomiting and immunotoxicity in animals [7, 8, 23, 25, 30]. Consistent with this, DON is stable during the storage and processing of agricultural products [27, 29]. Toxic effects of DON on farm animals have repeatedly been reviewed with the anorectic and immune-modulatory effects being most pronounced in pigs [4, 5] (http://www.efsa.europa.eu/de/efsajournal/doc/73.pdf). Human food poisoning after ingestion of DON has also been reported. The symptoms described include abdominal pain or a feeling of fullness in the abdomen, dizziness, headache, throat irritation, nausea, vomiting, diarrhea and blood in stools [28]. DON suppresses normal immune response to pathogens and simultaneously induces autoimmune-like effects, which are similar to human immunoglobulin A ( $\operatorname{Ig} \mathrm{A})$ nephropathy $[2,16,24]$.

The toxicokinetic characteristics and tissue residues of

*Correspondence to: Poapolathep, A., Department of Pharmacology, Faculty of Veterinary Medicine, Kasetsart University, Bangkok 10900, Thailand.

e-mail: fvetamp@hotmail.com; fvetamp@ku.ac.th

(C2015 The Japanese Society of Veterinary Science

This is an open-access article distributed under the terms of the Creative Commons Attribution Non-Commercial No Derivatives (by-nc-nd) License $<$ http://creativecommons.org/licenses/by-nc-nd/3.0/>.
DON have been studied in livestock and mice, but limited information is available on the fate and tissue disposition of DON in broilers. We studied therefore the fate and tissue residues of DON in broiler chickens by determining toxicokinetic parameters and toxin depletion in various tissues.

DON purchased from Wako Chemical Co. (Tokyo, Japan) was dissolved in $0.9 \%$ physiologic saline to the final concentration of $2 \mathrm{mg} / \mathrm{m} l$ for administration. Other reagents and chemicals of an analytical grade were purchased from Sigma Chemical Co. (St. Louis, MO, U.S.A.). Purified water was produced using the Milli-Q water purification system from Millipore, Inc. (Bedford, MA, U.S.A.).

Three-week-old female broiler chickens (average body weight, $1.24 \pm 0.21 \mathrm{~kg}$ ) were obtained from a chicken farm (CP Group Co.), Saraburi Province, Thailand, and acclimatized for 1 week. Each bird was placed in individual stainless-steel cages at the Laboratory Animal Facility, Faculty of Veterinary Medicine, Kasetsart University, with water and feed available ad libitum. All experimental procedures were ethically approved by Kasetsart University Animal Care and Use Committee.

In the first experiment, toxicokinetic characteristics of DON were investigated using ten broilers divided into 2 groups $(n=5)$. After overnight fasting, each group was administered intravenously (i.v.) or orally (p.o.) with DON at a dose of $1.0 \mathrm{mg} / \mathrm{kg}$ BW. This dose level was selected based on previous studies by Anonymus [1] and Poapolathep et al. [17]. Following i.v. or p.o. administration of DON, there were no any adverse effects in chickens. $2.5 \mathrm{ml}$ blood samples was collected from the wing veins of each animal with heparinized syringes at $0,5,15$ and $30 \mathrm{~min}$ and at 1, 2, 4, 8 and $12 \mathrm{hr}$ after DON administration. Plasma was separated by centrifugation $(1,968 \times g)$ for $15 \mathrm{~min}$.

In the second experiment, tissue residues of DON were investigated using 25 broilers. Twenty of them were orally administered with DON at a dose of $1 \mathrm{mg} / \mathrm{kg}$ of BW, and 
5 were orally administered with $0.9 \%$ physiologic saline as a control. They were sacrificed by i.v. administration of thiopentone sodium at a dose of $20 \mathrm{mg} / \mathrm{kg} \mathrm{BW}$. Tissue samples, including livers, kidneys, muscle and small intestines, were taken from 5 birds each at 1, 3, 6 or $12 \mathrm{hr}$ after administration. Excreta were collected at 0, 1, 3, 6 and $12 \mathrm{hr}$ after administration. All samples were frozen at $-20^{\circ} \mathrm{C}$ until analysis.

DON was extracted from blood plasma as described previously with some modifications $[17,32]$. Briefly, $1 \mathrm{~m} l$ of plasma diluted with $0.5 \mathrm{~m} l$ of $0.01 \mathrm{M}$ phosphate buffer (PB, pH 6.8) was applied on a ChemElut column (Varian Inc., Palo Alto, CA, U.S.A.), which was then eluted with $50 \mathrm{~m} l$ of ethyl acetate. The eluate was evaporated to dryness under vacuum at $40^{\circ} \mathrm{C}$, dissolved in $2 \mathrm{ml}$ of $5 \%$ polyethylene glycol (PEG) and filtrated with a Minisart ${ }^{\circledR}$ RC filter (pore size: $0.45 \mu \mathrm{m}$, Sartorius AG, Goettingen, Germany). The filtrate was applied on an immunoaffinity column (IAC, DONPrep ${ }^{\circledR}$, R-Biopharm Rhone Ltd., Darmstadt, Germany). After the column was washed twice with $2.5 \mathrm{ml}$ of water and flushed with air, DON was eluted with $3 \mathrm{ml}$ of methanol. The eluate was then evaporated to dryness under a nitrogen stream at $50^{\circ} \mathrm{C}$ on a heating block. The residue was reconstituted with $1 \mathrm{~m} l$ of methanol/water $(10 / 90, \mathrm{v} / \mathrm{v})$. After being passed through a Minisart ${ }^{\circledR} \mathrm{RC}$ filter (pore size: $0.45 \mu \mathrm{m}$, Sartorius AG), the reconstituted residue was analyzed by liquid chromatography/tandem mass spectrometry (LC/MS/ MS).

Preparation of tissue samples for DON analyses was performed according to the method described previously, with some modifications [22, 31]. Tissues (4 $\mathrm{g}$ of each tissue sample) were homogenized in $8 \mathrm{ml}$ of water (Milli-Q) with an Ultra-Turrax homogenizer (IKA Works, Inc., Wilmington, DE, U.S.A.). The homogenates were mixed with $16 \mathrm{~m} l$ of acetonitrile (ACN), and the supernatant was separated by centrifugation at $1,968 \times g$ for $15 \mathrm{~min}$. Aliquot samples of $5.6 \mathrm{~m} l$ per each tissue sample were passed through a charcoal alumina column (Trilogy Analytical Laboratory, Washington, MO, U.S.A.). DON was eluted with $10 \mathrm{~m} l$ of ACN/ water $(21 / 4, v / v)$ and evaporated to dryness under a nitrogen stream at $50^{\circ} \mathrm{C}$. The sample was subjected to LC/MS/MS.

The LC analysis was performed using an Agilent 1200 series system consisting of a binary high-pressure gradient pump, a vacuum solvent degassing unit, an automatic sample injector and a column thermostat (Agilent Technologies, Waldbronn, Germany) equipped with a Poroshell 120 ECC18 column $(2.7 \mu \mathrm{m}, 3.0 \times 50 \mathrm{~mm})$ (Agilent Technologies, Palo, Alto, CA, U.S.A.) maintained at $40^{\circ} \mathrm{C}$. The LC mobile phase program consisted of a binary gradient of the $5 \mathrm{mM}$ ammonium acetate with $0.1 \%$ acetic acid in water (mobile phase A) and the $5 \mathrm{mM}$ ammonium acetate with $0.1 \%$ acetic acid in methanol (mobile phase B). The composition started out at $5 \%$ mobile phase B and increased linearly to $70 \%$ mobile phase B by $7 \mathrm{~min}$. The mobile phase then returned to $5 \%$ methanol by $8 \mathrm{~min}$, and the column was equilibrated for $2 \mathrm{~min}$. The flow rate was $250 \mu \mathrm{l} / \mathrm{min}$, the injection volume was $5 \mu l$, and the needle was flushed with $250 \mu l$ of $100 \%$ methanol between samples.

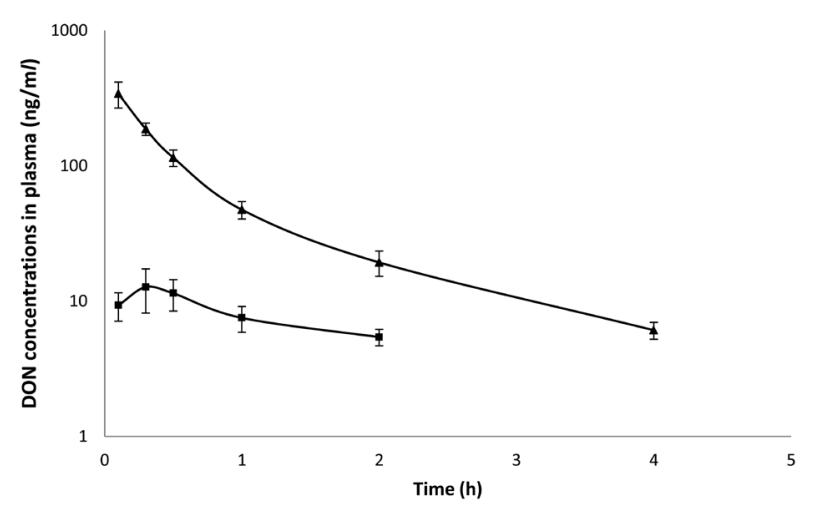

Fig. 1. Mean values ( \pm SD) of deoxynivalenol concentrations in plasma broiler chickens at a dosage of $1 \mathrm{mg} / \mathrm{kg} \mathrm{BW}$; ( $\boldsymbol{\Delta}$ ) intravenous administration, $(\mathbf{a})$ oral administration $(n=5)$.

Mass spectrometry was performed using an Agilent Technologies 6460 triple guard mass spectrometer equipped with an electrospray ionization (ESI) source and Agilent MassHunter Workstation Software version 1.2. ESI-MS/ MS was operated at unit mass resolution in multiple reaction monitoring (MRM) negative ion mode with the following settings: nebulizer gas pressure (NEB): 45 psi, gas flow $5.0 \mathrm{ll}$ $\mathrm{ml}$, gas temperature $300^{\circ} \mathrm{C}$ and Capillary voltage: $-3500 \mathrm{~V}$. The molecular ions and fragments were as follows: Q1: $\mathrm{m} / \mathrm{z}$ 355 [M-H] $]^{-}$, Q3 (1): $m / z$ 265, CE (1): 5 eV, Q3 (2): $m / z 59.1$ and $\mathrm{CE}(2): 9 \mathrm{eV}$.

To evaluate recovery, DON was added to samples of blank plasma and tissues to yield final DON concentrations of 1,5 , $10,50,100$ and $500 \mathrm{ng} / \mathrm{ml}(\mathrm{ng} / \mathrm{g})$ and analyzed in duplicate. The mean $( \pm \mathrm{SD})$ recoveries of DON were $91.16 \pm 4.23 \%$, $83.62 \pm 2.14 \%, 84.67 \pm 5.18 \%, 76.36 \pm 3.15 \%, 83.11 \pm 2.66$ and $73.69 \pm 3.06 \%$ in the plasma, liver, kidney, muscle, small intestine and excreta, respectively. The limit of detection (LOD) of DON was $1 n \mathrm{~g} / \mathrm{m} l(n \mathrm{~g} / \mathrm{g})$. The $r^{2}$ value of the DON calibration curves was 0.996 , and the precision and accuracy indicated the method to be repeatable. The intra- and inter-day precisions were $<11 \%$.

The concentration of DON in plasma was pharmacokinetically analyzed using a two-compartment model with the PK Solutions 2.0 $0^{\mathrm{TM}}$ Program (Summit Research Services, Montrose, CO, U.S.A.) including $K_{e l}$ (elimination rate constant), $K_{12}, K_{21}$ (micro-rate constants), $A U C_{0-\infty}$ (area under the curve), $t_{1 / 2 \beta}$ (elimination half-life), $t_{1 / 2 \alpha}$ (distribution half-life), $V_{d \text { (area) }}$ (volume of distribution), $\mathrm{Cl}$ (clearance) and $M R T$ (mean residence time). The absolute oral bioavailability (Fp.o.) was calculated using the following equation: $(\%) \mathrm{F}=($ AUCp.o. $) /($ AUCi.v. $) \times 100$.

DON was detectable in plasma following a single i.v. or p.o. administration. The semi-logarithmic plots of the mean $( \pm \mathrm{SD})$ plasma concentration-time curves of DON are shown in Fig. 1. DON was detectable from 5 min to $4 \mathrm{hr}$ after i.v. administration and from $5 \mathrm{~min}$ to $2 \mathrm{hr}$ after p.o. administration. The plasma profile displayed a rapid decrease in the DON concentration with time in both the groups. The data were shown to best fit a two-compartment model. As shown 
Table 1. Mean $\pm \mathrm{SD}$ value of the toxicokinetic parameters of deoxynivalenol following a single intravenous or oral administration at a dosage of $1 \mathrm{mg} / \mathrm{kg}$ BW in broiler chickens $(\mathrm{n}=5)$

\begin{tabular}{lccc}
\hline $\begin{array}{c}\text { Toxicokinetic } \\
\text { parameters (unit) }\end{array}$ & i.v. & p.o. & $P$-value \\
\hline$K_{e l}(\mathrm{hr})$ & $0.57 \pm 0.098$ & $0.32 \pm 0.17$ & 0.02 \\
$K_{l 2}\left(\mathrm{hr}^{-1}\right)$ & $1.14 \pm 0.57$ & - & - \\
$K_{2 l}\left(\mathrm{hr}^{-1}\right)$ & $0.92 \pm 0.22$ & - & - \\
$t_{l / 2 \alpha}(\mathrm{hr})$ & $0.21 \pm 0.10$ & $0.34 \pm 0.12$ & 0.09 \\
$t_{l / 2 \beta}(\mathrm{hr})$ & $1.25 \pm 0.25$ & $2.69 \pm 0.96$ & 0.01 \\
$C l(l / \mathrm{hr} / \mathrm{kg})$ & $4.16 \pm 0.42$ & $2.83 \pm 0.74$ & 0.01 \\
$V_{d}(l / \mathrm{kg})$ & $7.55 \pm 2.03$ & $10.04 \pm 3.09$ & 0.17 \\
$M R T(\mathrm{hr})$ & $2.10 \pm 0.54$ & $3.92 \pm 1.76$ & 0.06 \\
$C_{\max }(\mathrm{ng} / \mathrm{m} l)$ & - & $12.73 \pm 4.06$ & - \\
$T_{\max }(\mathrm{min})$ & - & $15.0 \pm 0.0$ & - \\
$F_{\text {p.o. }}(\%)$ & - & $15.46 \pm 4.02$ & - \\
\hline
\end{tabular}

$K_{e l}=$ elimination rate constant; $K_{12}, K_{2 I}=$ micro-rate constants. $t_{1 / 2 \alpha}=$ distribution half-life; $t_{1 / 2 \beta}=$ elimination half-life; $\mathrm{CL}=$ clearance. $V_{d}=$ Volume of distribution; $M R T=$ mean residence time, $C_{\max }=$ maximum concentration. $T_{\max }=$ time at maximum concentration; $F_{p o}=$ oral bioavailability. A statistical difference was calculated using the Student's $t$-test; $P<0.05$ was judged to be significant; $P<0.01$ was judged to be highly significant.

Table 2. Mean \pm SD residue concentrations of deoxynivalenol (DON) in various tissues following a single oral administration at $1 \mathrm{mg} / \mathrm{kg} \mathrm{BW}$ in broiler chickens $(\mathrm{n}=5)$

\begin{tabular}{lccccc}
\hline \multirow{2}{*}{ Time $(\mathrm{hr})$} & \multicolumn{5}{c}{ DON concentration $(n \mathrm{~g} / \mathrm{g})$} \\
\cline { 2 - 6 } & Liver & Kidney & Small intestine & Muscle & Excreta \\
\hline 1 & $5.58 \pm 0.23$ & $6.18 \pm 2.74$ & $57.05 \pm 10.95$ & $4.25 \pm 1.56$ & $94.49 \pm 12.42$ \\
3 & $2.23 \pm 0.33$ & $2.35 \pm 0.75$ & $2.55 \pm 0.08$ & ND & $74.58 \pm 7.77$ \\
6 & ND & ND & ND & ND & $27.93 \pm 0.90$ \\
12 & ND & ND & ND & ND & $37.34 \pm 6.78$ \\
\hline
\end{tabular}

$\mathrm{ND}=$ not detected

in Table 1, the values for the $t_{1 / 2 \beta}, V_{d}, C l$ and $M R T$ in iv treated birds were $1.25 \pm 0.25 \mathrm{hr}, 7.55 \pm 2.03 \mathrm{l} / \mathrm{kg}, 4.16 \pm$ $0.42 \mathrm{l} / \mathrm{hr} / \mathrm{kg}$ and $2.10 \pm 0.54 \mathrm{hr}$, respectively. The maximum plasma concentration $\left(C_{\max }\right)$ of DON was $12.73 \pm 4.56 \mathrm{ng} / \mathrm{ml}$ at $15 \mathrm{~min}$ after p.o. administration. The absorption of DON from gastrointestinal tract was low with an average absolute oral bioavailability of $15.46 \%$. DON was also detected in excreta up to $12 \mathrm{hr}$ following p.o. administration. The LCMS/MS profile for various tissues showed that DON was measurable up to $3 \mathrm{hr}$ in livers, kidneys and small intestines, whereas it was detectable up to $1 \mathrm{hr}$ in muscle after p.o. administration (Table 2). The maximum levels of DON in the liver, kidney, small intestine and muscle were $2.58 \pm$ $0.23 n \mathrm{~g} / \mathrm{g}, 6.18 \pm 2.74 n \mathrm{~g} / \mathrm{g}, 57.05 \pm 10.95 n \mathrm{~g} / \mathrm{g}$ and $4.25 \pm$ $1.56 \mathrm{ng} / \mathrm{g}$, respectively, at $1 \mathrm{hr}$ after p.o. administration.

DON is a major contaminant in food and feedstuffs. Our study was designed to characterize the fate and tissue residues of DON after i.v. or p.o. administration at a dose of $1 \mathrm{mg} / \mathrm{kg}$ BW in broiler chickens. De-epoxydeoxynivalenol (DOM-1), a major metabolite of DON formed in animals, was not investigated, because Prelusky et al. [21] reported that 95\% was presented as the parent toxin, metabolic conversion to DON conjugate was estimated at less than $5 \%$, and the nontoxic DOM-1 was not detected after oral administration of DON in animals. A previously reported pharmacokinetic study described DON in plasma of pigs, broilers and sheep $[3,9,15,18,19,21]$. Following i.v. administration, the $t_{1 / 2 \beta}$ indicates the overall rate of elimination and allows the prediction of DON accumulation with a value for DON of 1.25 $\mathrm{hr}$ in broiler chickens. The mean residence time (MRT, the average time that DON molecule resides in the body) was $2.10 \mathrm{hr}$ after i.v. administration. DON appears to have been excreted rapidly in broiler chickens. Thus, about $99 \%$ of the DON from broiler plasma was cleared within $9 \mathrm{hr}$ after i.v. administration. The $t_{1 / 2 \beta}$ of DON obtained in this study was longer than that reported (30 $\mathrm{min})$ earlier in broilers [13]. However, that study did not determine the residue of DON in edible tissues of broilers. Furthermore, the $t_{1 / 2 \beta}$ of DON in the present study was shorter than that reported in growing pigs $(2.1-8.8 \mathrm{hr})[17,21]$, whereas it was similar in sheep $(1.1-1.3 \mathrm{hr})[18,20]$. The $\mathrm{V}_{\mathrm{d}}$ of DON in broiler chickens was $7.55 \mathrm{l} / \mathrm{kg}$ after i.v. administration. These results suggest that DON might have penetrated to various tissues, although it appears to be excreted rapidly after i.v. administration in broiler chickens.

Following p.o. administration, the $C_{\max }$ was $12.73 \mathrm{ng} / \mathrm{ml}$, 
and the absolute oral bioavailability of DON was $15 \%$ in broiler chickens in this study. Prelusky et al. [19] reported a rapid transport of DON-derived radioactivity through the alimentary tract of broiler chickens, indicating the poor absorption of DON. The $F_{\text {p.o. }}$ of DON in broiler chickens of the present study was lower than that in pigs (48-110\%) $[9,21]$, but it was higher than that in sheep [18]. The $F_{p . o .}$ of DON in the present study corresponded well to the previous findings in broiler chickens (19\%) [15]. The level of DON in various tissues, including the liver, kidney and small intestine, was detectable up to $3 \mathrm{hr}$, whereas it was measurable up to $1 \mathrm{hr}$ in muscle after p.o. administration of DON in broiler chickens. The tissue level of DON was high in the small intestine, kidney, liver and muscle, in this order. This also indicates the ability of DON to penetrate into various tissues of broiler chickens, although the toxicokinetic study revealed a low absolute oral bioavailability. Taken together, it becomes clear that the small intestine, kidney, liver and muscle of broiler chickens could contribute to the human exposure to DON.

The lowest and highest tissue concentrations of DON were found in muscle $(4 \mathrm{ng} / \mathrm{g})$ and in small intestine $(57 \mathrm{ng} / \mathrm{g})$, respectively. Regarding the acute and chronic threshold of $8 \mu \mathrm{g} / \mathrm{kg} \mathrm{BW}$ per day [11] (http://www.who.int/ foodsafety/chem/summary 72 rev.pdf) and $1 \mu \mathrm{g} / \mathrm{kg} \mathrm{BW}$ per day [26] (http://ec.europa.eu/food/fs/sc/scf/out123_en.pdf), it is unlikely therefore that DON will cause harm to humans whose average meat consumption was $42.9 \mathrm{~kg} /$ person/year or average of $117 \mathrm{~g} /$ day [6] (http://www.fao.org/3/a-i4136e. pdf). The results obtained in this study supplemented those of our previous study may contribute to our understanding of toxicokinetic characteristics and residues of mycotoxins, particularly DON, in food producing animals.

ACKNOWLEDGMENT. This study was supported by the Kasetsart University Research and Development Institute, Bangkok, Thailand.

\section{REFERENCES}

1. Anonymus. 2006. Commision recommendation 2006/576/EG on the presence of deoxynivalenol, zearalenone, ochratoxin A, T-2 and HT-2 and fumonisins in products intended for animal feeding. Off. J. Eur. Commun. L229/7.

2. Berger, J. 1969. IgA glomerular deposits in renal disease. Transplant. Proc. 1: 939-944. [Medline]

3. Coppock, R. W., Swanson, S. P., Gelberg, H. B., Koritz, G. D., Hoffman, W. E., Buck, W. B. and Vesonder, R. F. 1985. Preliminary study of the pharmacokinetics and toxicopathy of deoxynivalenol (vomitoxin) in swine. Am. J. Vet. Res. 46: 169-174. [Medline]

4. Döll, S. and Dänicke, S. 2011. The Fusarium toxins deoxynivalenol (DON) and zearalenone (ZON) in animal feeding. Prev. Vet. Med. 102: 132-145. [Medline] [CrossRef]

5. EFSA. 2004. Opinion of the scientific panel on contaminants in the food chain on a request from the commission related to deoxynivalenol (DON) as undesirable substance in animal feed. EFSA J.73 Available from http://www.efsa.europa.eu/de/efsajournal/doc/73.pdf.

6. FAO, 2014. Food Outlook Biannual Report on Global Food
Markets. Available from http://www.fao.org/3/a-i4136e.pdf.

7. Friend, D. W., Trenholm, H. L., Elliot, J. I., Thompson, B. K. and Hartin, K. E. 1982. Effect of feeding vomitoxin-contaminated wheat to pigs. Can. J. Anim. Sci. 62: 1211-1222. [CrossRef]

8. Forsyth, D. M., Yoshizawa, T., Morooka, N. and Tuite, J. 1977. Emetic and refusal activity of deoxynivalenol to swine. Appl. Environ. Microbiol. 34: 547-552. [Medline]

9. Goyarts, T. and Dänicke, S. 2006. Bioavailability of the Fusarium toxin deoxynivalenol (DON) from naturally contaminated wheat for the pig. Toxicol. Lett. 163: 171-182. [Medline] [CrossRef]

10. IARC. 1993. Toxins derived from Fusarium graminearum, $F$. culmorum and F. crookwellense: zearalenone, deoxynivalenol, nivalenol, and Fusarenon-X. pp. 397-444. In: IARC Monographs on the Evaluation of Carcinogenic Risk to Humans, vol. 56. International Agency for Research of Cancer, Lyon.

11. JECFA. 2010. Joint FAO/WHO Expert Committee on Food Additives. Sventy-second meeting Rome, 16-25 February 2010, Summary and conclusions. Issued 16th March, 2010. Available from http://www.who.int/foodsafety/chem/summary72_rev.pdf.

12. Jelinek, C. F., Pohland, A. E. and Wood, G. E. 1989. Worldwide occurrence of mycotoxins in food and feeds: An Update. J. Assoc. Off. Anal. Chem. 72: 223-230. [Medline]

13. McMullen, M., Jones, R. and Gallenberg, D. 1997. Scab of wheat and barley: A re- emerging disease of devastating impact. Plant Dis. 81: 1340-1348. [CrossRef]

14. Moos, M. O. 2002. Mycotoxin review-2. Fusarium. Mycologist 16: $158-161$

15. Osselaere, A., Devreese, M., Goossens, J., Vandenbroucke, V., De Baere, S., De Backer, P. and Croubels, S. 2013. Toxicokinetic study and absolute oral bioavailability of deoxynivalenol, T-2 toxin and zearalenone in broiler chickens. Food Chem. Toxicol. 51: 350-355. [Medline] [CrossRef]

16. Pestka, J. J. and Smolinski, A. T. 2005. Deoxynivalenol: toxicology and potential effects on humans. J. Toxicol. Environ. Health B Crit. Rev. 8: 39-69. [Medline] [CrossRef]

17. Poapolathep, A., Poapolathep, S., Sugita-Konishi, Y., Wongpanit, K., Machii, K., Itoh, Y. and Kumagai, S. 2010. The effect of naringenin on the fate and disposition of deoxynivalenol in piglets. J. Vet. Med. Sci. 72: 1289-1294. [Medline] [CrossRef]

18. Prelusky, D. B., Veira, D. M. and Trenholm, H. L. 1985. Plasma pharmacokinetics of the mycotoxin deoxynivalenol following oral and intravenous administration to sheep. J. Environ. Sci. Health B 20: 603-624. [Medline] [CrossRef]

19. Prelusky, D. B., Hamilon, R. M. G., Trenholm, H. L. and Miller, J. D. 1986. Tissue distribution and excretion of the radioactivity following administration of ${ }^{14} \mathrm{C}$-labeled deoxynivalenol to White Leghorn hens. Fundam. Appl. Toxicol. 7: 635-645. [Medline] [CrossRef]

20. Prelusky, D. B., Veira, D. M., Trenholm, H. L. and Foster, B. C. 1987. Metabolic fate and elimination in milk, urine and bile of deoxynivalenol following administration to the lactating sheep. J. Environ. Sci. Health B 22: 125-148. [Medline] [CrossRef]

21. Prelusky, D. B., Hartin, K. E., Trenholm, H. L. and Miller, J. D. 1988. Pharmacokinetic fate of ${ }^{14} \mathrm{C}$-labelled deoxynivalenol in swine. Fundam. Appl. Toxicol. 10: 276-286. [Medline] [CrossRef]

22. Prelusky, D. B. and Trenholm, H. L. 1991. Tissue distribution of deoxynivalenol in swine dosed intravenously. J. Agric. Food Chem. 39: 748-751. [CrossRef]

23. Prelusky, D. B., Gerdes, R. G., Underhill, K. L., Rotter, B. A., Jui, P. Y. and Trenholm, H. L. 1994. Effects of low-level dietary deoxynivalenol on the Haematological and clinical parameters of the pig. Nat. Toxins 2: 97-104. [Medline] [CrossRef] 
24. Rasooly, L. and Pestka, J. J. 1992. Vomitoxin-induced dysregulation of serum $\operatorname{IgA}$, IgM and $\operatorname{IgG}$ reactive with gut bacterial and self antigens. Food Chem. Toxicol. 30: 499-504. [Medline] [CrossRef]

25. Rotter, B. A., Prelusky, D. B. and Pestka, J. J. 1996. Toxicology of deoxynivalenol (vomitoxin). J. Toxicol. Environ. Health 48: 1-34. [Medline] [CrossRef]

26. SCF, Scientific Committee on Food, 2002. Opinion of the Scientific Committee on Food on Fusarium toxins. Part 6: Group evaluation of T-2 toxin, HT-2 toxin, nivalenol and deoxynivalenol, adopted on 26 February 2002. DCF/CS/CNTM/MYC/27 Final. Available from: http://ec.europa.eu/food/fs/sc/scf/out123 en.pdf.

27. Scott, P. M. 1991. Possibilities of reduction or elimination of mycotoxins present in cereal grains. pp. 529-572. In: Cereal Grain: Mycotoxins, Fungi and Quality in Drying and Storage (Chelkowski, J. ed.), Elsevier, Amsterdam.

28. Sudakin, D. L. 2003. Trichothecenes in the environment: relevance to human health. Toxicol. Lett. 143: 97-107. [Medline] [CrossRef]

29. Sugita-Konishi, Y., Park, B. T., Kobayashi-Hattori, K., Tanaka,
T., Chonan, T., Yoshikawa, K. and Kumagai, S. 2006. Effect of cooking process on the deoxynivalenol content and its subsequent cytotoxicity in wheat products. Biosci. Biotechnol. Biochem. 70: 1764-1768. [Medline] [CrossRef]

30. Trenholm, H. L., Hamilton, R. M. G., Friend, D. W., Thompson, B. K. and Hartin, K. E. 1984. Feeding trials with vomitoxin (deoxynivalenol)-contaminated wheat: Effects on swine, poultry, and dairy cattle. J. Am. Vet. Med. Assoc. 185: 527-531. [Medline]

31. Trenholm, H. L., Warner, R. M. and Prelusky, D. B. 1985. Assessment of extraction procedures in the analysis of naturally contaminated grain products for deoxynivalenol (vomitoxin). $J$. Assoc. Off. Anal. Chem. 68: 645-649. [Medline]

32. Valenta, H., Dänicke, S. and Döll, S. 2003. Analysis of deoxynivalenol and de epoxy-deoxynivalenol in animal tissues by liquid chromatography after clean-up with an immunoaffinity column. Mycotoxin Res. 19: 51-55. [Medline] [CrossRef]

33. van Egmond, H. P., and Speijers, G. J. A. 1999. Natural toxins I. Mycotoxins. pp. 341-355. In: International Food Safety Handbook (van der Heijden, K., Younes, M., Fishbein, L. and Miller, S. eds.), Marcel Dekker Inc., New York. 